Document downloaded from:

http://hdl.handle.net/10251/79127

This paper must be cited as:

Fabra Crespo, M.; Rojas Briales, E. (2015). Comparative analysis on the communication strategies of the forest owners associations in Europe. Forest Policy and Economics. 50:2030. doi:10.1016/j.forpol.2014.06.004.

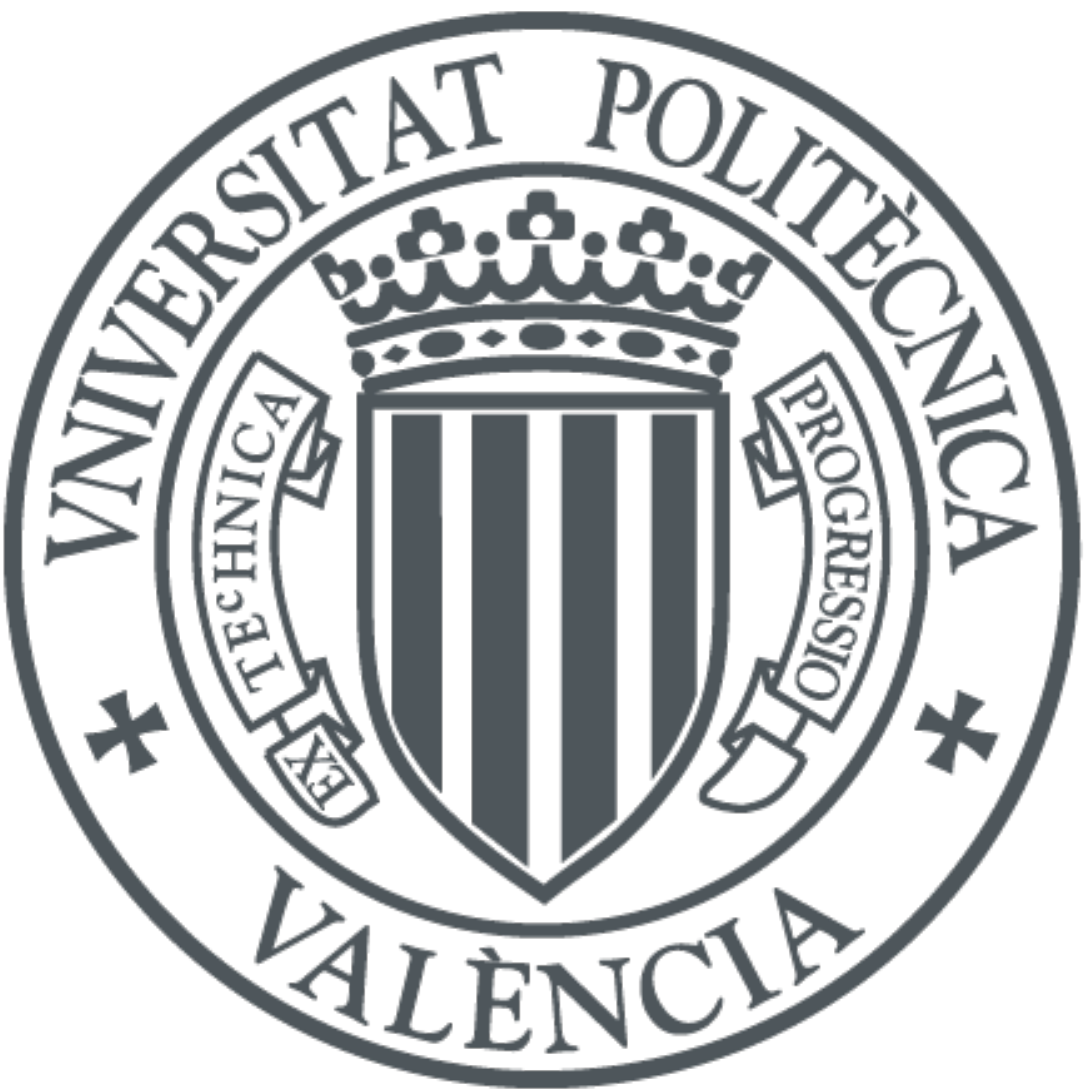

The final publication is available at

http://dx.doi.org/10.1016/j.forpol.2014.06.004

Copyright Elsevier

Additional Information 


\title{
Comparative analysis on the communication strategies of the forest owners' associations in Europe
}

\author{
M. Fabra-Crespo1 and E. Rojas-Briales2 \\ ${ }^{1}$ Miguel Fabra-Crespo (Corresponding author) \\ University of Eastern Finland \\ School of Forest Sciences \\ Joensuu FI-80100 \\ Phone: +358505997101 \\ mfabracrespo@yahoo.com \\ ${ }^{2}$ Eduardo Rojas -Briales * \\ Food and Agriculture Organization of the United Nations \\ Viale delle terme di Caracalla \\ 00153 Rome, Italy \\ Phone: +3906 57051 \\ eduardo.rojas@fao.org
}

* The present publication corresponds to previous research conducted as professor of the Universitat Politècnica de València and not under FAO. There for, the conclusions included in this paper should not be understood as any official position of FAO. 


\begin{abstract}
This research reports a comparative analysis of the communication strategy that forest owners' associations across Europe use to influence society on one side and the decision-makers on the other, in order to fulfill forest owners' interests. $60 \%$ of Europe's forests are privately owned by an estimated number of 16 million forest owners, who are represented by forest owners associations. One of its main functions is to influence the public perceptions on forests and forestry. In this article it is analyzed how a specific forestry stakeholder fixes its strategies to communicate with and lobby society in order to get acceptability for their proposals/demands. Open-end surveys have been used as a source of information in 2006 and repeated in 2012. Besides of the comparison among countries, a comparison along the time has been also performed. The whole communication frame is analyzed, considering the objectives, the structure, the messages, the channels, and the evaluation. The main conclusions that arise are: first, the temporary comparison (20062012) results into an improvement in several issues; second, there is room for improvement of professionalization of communication in forest owners' associations in Europe; third, social research into public perception of forestry might help to define communication strategies.
\end{abstract}

Keywords: advocacy; social influence; grassroots; treetops; environmental communication, forest owners

\title{
HIGHLIGHTS
}

- Forest owners' communication and lobbying strategies are compared in Europe.

- 15 forest owners associations contributed to the analysis in 2006 and 2012.

- Both, treetops and grassroots approaches, are exercised by the associations.

- New messages on biomass, climate change, green economy, etc are rising. 


\section{1.- Introduction}

Forest sector is not profitable directly in most areas of the World. When forests produce more environmental services than direct products, the corresponding governance mechanisms are key, especially in non-state ownership. In urban societies forests are key for recreation and their management is overlapping with that use. Conflicting views on forest management arise as forests become the backyard of the people. Therefore in order to overpass market failures, social support is needed to finance the expenses which keep the sustainable forest management ongoing; very especially in cases of high risks (e.g. forest fires in Mediterranean region, and in mountainous regions) and on reconstruction needs.

Communication is a particularly important task, because forestry is a minority issue in most countries, mainly due to its weak economic relevance for society in the context of a strongly urbanized society. This means that in the market-oriented political systems, the articulation of forestry in the media becomes a challenge, which consequently has to be put a lot of effort into communication to be heard by the society and its politicians (Moscovici, 1994).

European studies of public perception (European Commission, 2009) reveal that forestry issues are not well understood outside the small forestry community and suggest that there is a significant gap between public understanding and reality. Public participation concerning forestry issues hasn't been as successful as expected (Aasetre, J. 2006; Saarikoski, H. et al. 2010). The recent proposal for an EU Forest Communication Strategy (European Commission, 2011) reinforces the idea on the need of further knowledge on this subject, as it has been materialized under the concept of the International Year of Forests 2011, and the international day of the forests (March 21) from 2013 onwards.

Forests are widely in private ownership in most European countries (more than $70 \%$ in Western Europe and less than 50\% in Eastern Europe, but increasing), consequently their management is dependent on its owners' decisions (FAO, 2011). Therefore private forest owners are in most countries an important link within the forest sector chain, and they get a voice, with their claims considered, as far as they are organized around an association. Those claims differ, as private forest owners present different management motives around Europe (Pollumae et al. 2014; Novais, A and Canadas MJ. 2010). Even some basic data on forest owners, are not well known in Europe (FAO, 2010), as for example could be: total number of forest owners, profile of forest owners, sizes of ownerships, personal investment in forests, revenues to investments, etc

Within this frame of communication in the forest sector, this paper analyzes the strategies concerning how FOAs (Forest Owners Associations) communicate to decision-makers and to society in general. This article is not aiming a theoretical discussion on the subject, but analyses facts and discusses on how FOA'strategies on communication and lobbying could be improved in a practical way. Therefore the overall goal of the paper is to help to better understand the lobbying 
and communication strategies of forest owners associations, and its evolution during last years, because they can be very successful in influencing for the improvement of forestry and forest sector.

Timber prices for example, can be negotiated more efficiently organized around FOAs (Stordal, 2004) as well as supply flows can be channeled more efficiently. In addition, one of the main challenges is that the structure of family forest ownership is changing due to the age structure of the rural population, urbanization and inheritance.

Content analysis has been performed based on data collected by two surveys on national forest owners associations around Europe (11 countries in 2006 and 13 countries in 2012).

The article starts focusing on the different strategies for communication and the elements that compose it. Then it points on forest sector and forest owners. The results of the survey are presented according to the different elements that compose a communication frame process, to finally discuss on how to improve FOAs performance.

\section{2.- Objectives}

The objective of this article is to analyze through a case study the strategies used by forest owners associations in Europe to communicate and lobbying with society as well as with the decisionmakers. It combines two comparative analyses, between countries and between years. This analysis would contribute to the forest owners associations in order to bring further knowledge and therefore improve the FOAs actions of lobbying towards a more successful result.

\section{Strategies for communication and lobbying}

Lobbying is a communication activity (Tusinski, 2009), and as such follows a typical communication model with its four main components as source-message-channel-receiver (Berlo, 1960). Otherwise from a theoretical framework, in our view of lobbying as a social interaction, our interpretation is closer to the more developed social constructionist (Craig, 1999) who considers communication to be the product of the interactants sharing and creating meaning.

The concept of lobbying appears in theories of social influence as the process whereby people (through interest groups) directly or indirectly influence the thoughts, feelings and actions of others. It is linked to the expression and opinion rights of the organizations in those matters of public debate which could affect them directly (Bach and Unruh, 2005). Another definition is to analyze and understand a problem, in order to explain its relevance and consequences to those who hold the power to decide. 
However reconciling the demands of self-interested private interests with the interest of wider civil society represents the central problem of democratic life (Greenwood and Thomas, 1998). If lobbying is then seen as mutual beneficial exchange of information, therefore interest groups are representatives of organized civil society with capacity to contribute to democratic legitimacy.

The interest groups (or stakeholders) are individual groupings around particular common interests, which have as their substantial target the defense of these interests. According to the nature of these groups, they can be classified into the groups that defend material interests and those groups that defend the interests of morals and ideas $(\mathrm{Ok}, 2005)$. In the case presented at this article, forest owners have a mixed profile, because partly they defend economic interests as profitability, asset protection and freedom to manage their forests, but they also defend philosophical ideas concerning Nature itself, heritage or cultural landscape. Furthermore their personal attachment to their estates often has much more weight for traditional reasons (a forest that belongs to the same family for many generations) or values (environmental awareness).

Stakeholders show their interests to both decision-makers and to the society, as they need public support to address their interests to decision makers. Stakeholders use different communication tools to address to these two target groups of communication receivers (Janse, 2007). Public' perceptions as well as stakeholders' interests should be analyzed (Fabra-Crespo, M et al. 2012), for matching them and make them compatible, in order to produce proper communication strategies, which will reach the decision-makers whilst having the adequate social support (Cox, 2006). Full understanding on how communication flows in both senses, decision-makers to society and other way around, is a key factor in any policy analysis. Communication from stakeholders can be aimed straight at the politicians and decision-makers or indirectly through society as a whole or a group of representatives such as a group of environmental activists (Fazio and Gilbert, 2000).

An example of influence on forest policy at the European level was during the creation of the Natura 2000, were both ENGOs and forest owners associations pursued lobbying strategies to influence the new legislation (Weber and Christophersen, 2002).

According to the new model of effective lobbying strategies (Jaatinen, 1998) there are three main factors that constitute the contingency factors that are the following in order of importance: the opinion of the target of lobbying on certain issue, the direction and intensity of competition, and the support of mass media and citizens. The combination of states of these contingency factors leads to a different strategies to follow (Jaatinen, 1999).

In order to achieve a strategy, two main tactics can be adopted, treetops and grassroots tactics. Treetops tactics (direct lobbying) involve activating smaller (than in grassroots) numbers of more influential citizens to contact their local government representatives (Xifra, 1998). These are people with contacts and political savvy who can identify many business people or respected citizens able 
to clearly present the client's viewpoint on an issue. This is direct lobbying, which means negotiation via argumentation. This negotiation can be official or officious, public or secret.

Nowadays in the shift from representative to participatory democracy, decision-making shall be shared among those who have the responsibility to implement the measures (Buttoud and Samyn, 1999; Primmer and Kyllönen, 2006). In fact, many forest laws have been reformed in recent years around Europe and globally, and in some way or other they include the compulsory requirement to include the main forest stakeholders in policy decision-making processes. This often includes the constitution of official advisory bodies as well (Zimmermann and Schmithüsen, 2002). Consequently new participatory decision-making bodies have been constituted in many countries for many sectors (Cost e19, 2004), which is found an appropriate arena for treetops lobbying.

A different approach is the grassroots tactics (indirect lobbying) means taking action on public opinion, in order to indirectly influence decision-makers' viewpoints (Cottle and Howard, 2012). The main goal is to change their awareness about forestry, through grassroots actions first it is created the public interests for an issue (Ghai and Vivian, 1992). Grassroots campaigns including mass media play with the feelings, mobilizing family, friends and neighbors. The rationale for this (influence of the mass media) is that politicians have to worry about being reelected, so they care what voters think.
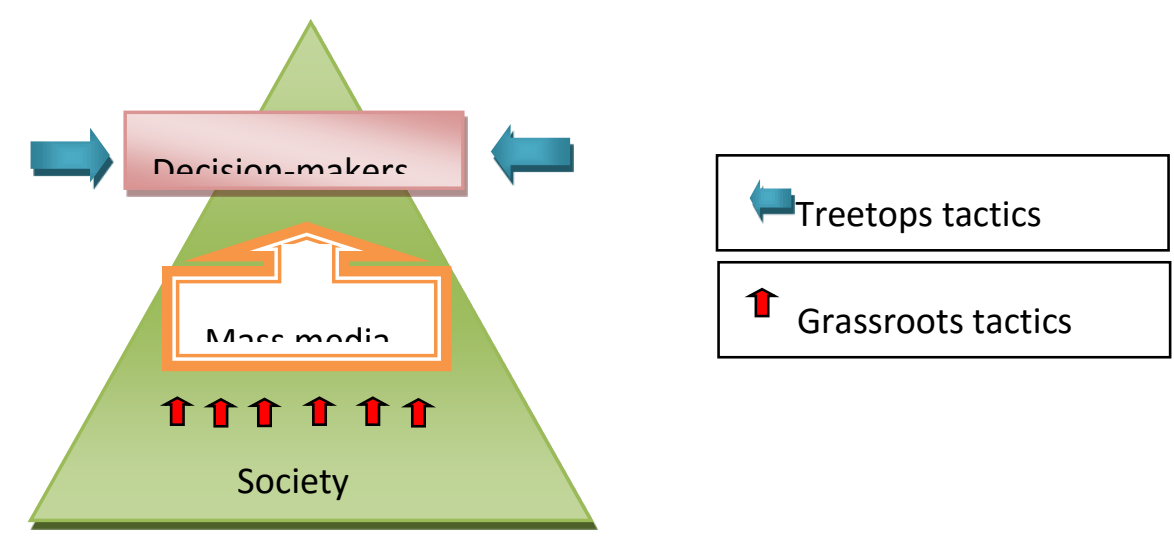

Figure 1.- Grassroots versus treetops tactics and mass media role. Source: Own

In general some of the main factors or variables characterizing the analytical frame of treetops versus grassroots lobbying strategies for any organization could be summarized as follows:

- In treetops focusing into staff able to mobilize public opinion and its support (such mass media professionals); whilst in grassroots focusing staff able to easily reach top decisionmakers (such more political oriented staff).

- In treetops allocating priority in their strategy for activities with the goal to reach decision makers and reflecting that into their budget; whilst in grassroots allocating clear priority to activities to shape opinion and support of the general public. 
- In treetops declaring as communication targets the high-position civil servants, politicians...; whilst in grassroots the target would become general public as children or families, or the mass media professionals as the journalists.

- In treetops using channels that reach the wide public as websites or newsletters; whilst in grassroots will use such as face to face meetings, forums...

\section{European forest ownership and the profile of forest owners}

The European continent, excluding the Russia, has nearly 210 million ha of forest and other wooded land. In the European Union (27) the area is 157 million ha, which represents $42 \%$ of its land (Forest Europe, 2011). Overall, forest land ownership is approximately equally distributed between public and private owners. In the EU, some $60 \%$ of forest areas privately owned (European Commission, 2007). However, in Western Europe two-thirds of forest land is privately owned, whereas in Eastern Europe forests are mainly in the public domain, though this is changing with restitution and privatization taking place in former socialist countries (CEPF, 2009).

The significance of forest resources for owners, as well as for the public, varies tremendously within the European countries (Hyttinen, 2001). One indicator of relative importance of forests is the forest area per capita, which ranges from 0.2 ha in the Netherlands to 4.0 ha in Finland. It is clear that the owner's expectations as well as public values related to forests cannot be the same in these two countries.

In the member countries of the European Union, there are approximately 16 million private individuals that can be classified as forest owners. They constitute an important part of society, accounting for up to $10 \%$ of the total European families. This means that it is almost certain that every person has a relative or a friend who owns forest despite an important share of them might not be conscious about it (scattered ownership). Private forest holdings have an average size of 6 ha but there is a huge range, with considerable variation among the countries in the average size of holdings (CEPF, 2009).

There are not many comprehensive studies on the profile of forest owners in Europe. Motivation, values and perceptions of forest owners classified into different categories, would enrich the knowledge about this social group and its influence on forest management. One empirical study that was based on six motivations and supplemented with nine attitudes resulted in four well-defined owner groups: materialistic, satisfied recreational, dissatisfied recreational and profit-seeking owners (Serbruyns and Luyssaert, 2006), as well as other studies classify them according to production and consumption objectives (Ní Dhubháin, 2007). Hence urbanization is breaking the links between humans and forests (Dominguez, 2008; Ziegenspeck et al., 2004)). Or the profile of non-financial-oriented owners (Urquhart and Courtney, 2011). 
Forest owners have the responsibility of a double task in communication: to promote the use of products and services coming from the forests, but also at the same time the most difficult: to promote other benefits that the forests are generating to the whole society, that are provided by forests without significant maket revenue, and all that managed by private forest owners in a big share of the territory.

In general, forest owners are well organized in Europe, in terms of group membership. Otherwise, this is not always evident, as the fact that there is an association does not prejudge its representativeness or capacity. In most countries forest owners' associations (FOA) have been established to promote sustainable forest management but still some other don't have FOAs, and this might be because the forest sector economy represents a small share, or because the private ownership is just in its beginning as in CIS countries (Glück, 2010).

The associations serve as a link between forest owners, represent them in forest policy making, and also provide support in timber sales and silvicultural operations in some of the countries. Forms of cooperation and resulting activities vary, ranging from low levels of commitment for purposes of information/education, to more structured participation for financial and timber marketing purposes. Likewise, the origins of cooperation differ from country to country, though common elements emerge (e.g. the role of government, reaction to a stimulus or threat) (Kittredge, 2005) with similarity to cooperatives and farmers unions.

Among all possible forest stakeholders for this research that could have been chosen, forest owners have been found to be the most interesting ones. Forest owners are represented by FOAs, which come aiming at some efficiency gains and purposive defense of common interests (Mendes, 2006), among others: gaining private forestry's participation in the forest policy processes. As forest owners are scattered around a huge territory and they represent a small share of the whole population, their weaknesses have to be overcome by creating vertical structure in associations, to gain power to lobby towards their common interests. Thus it is important link between forestry and society thanks to FOAs.

The Confederation of European Forest Owners (CEPF) is the most representative umbrella organization of national forest owner organizations in Europe. At international level, the IFFA International Family Forest Alliance was established in 2005 as a formal organization in order to become a more powerful voice for family forestry in relation to international organizations, such as the UN organizations and the World Bank. But still most of the countries outside Europe have weak FOAs structures. At a global scale, Europe (and USA, Japan, South Korea) are the exception as $80 \%$ of the total forest area is stated owned. 


\section{5.- Material and methods}

\section{1.- Materials}

Out of 21 CEPF country members it has been collected 11 respondents in 2006 and 14 in 2012 (Figure 2) from the FOA which are member of CEPF in each country, it haven gotten the most important countries involved, it can be also considered representative enough for Europe. In fact, they represent more than $75 \%$ (more than 100 million ha) of the total forest area and more than $80 \%$ (more than 300 million $\mathrm{m}^{3}$ ) of the wood production.

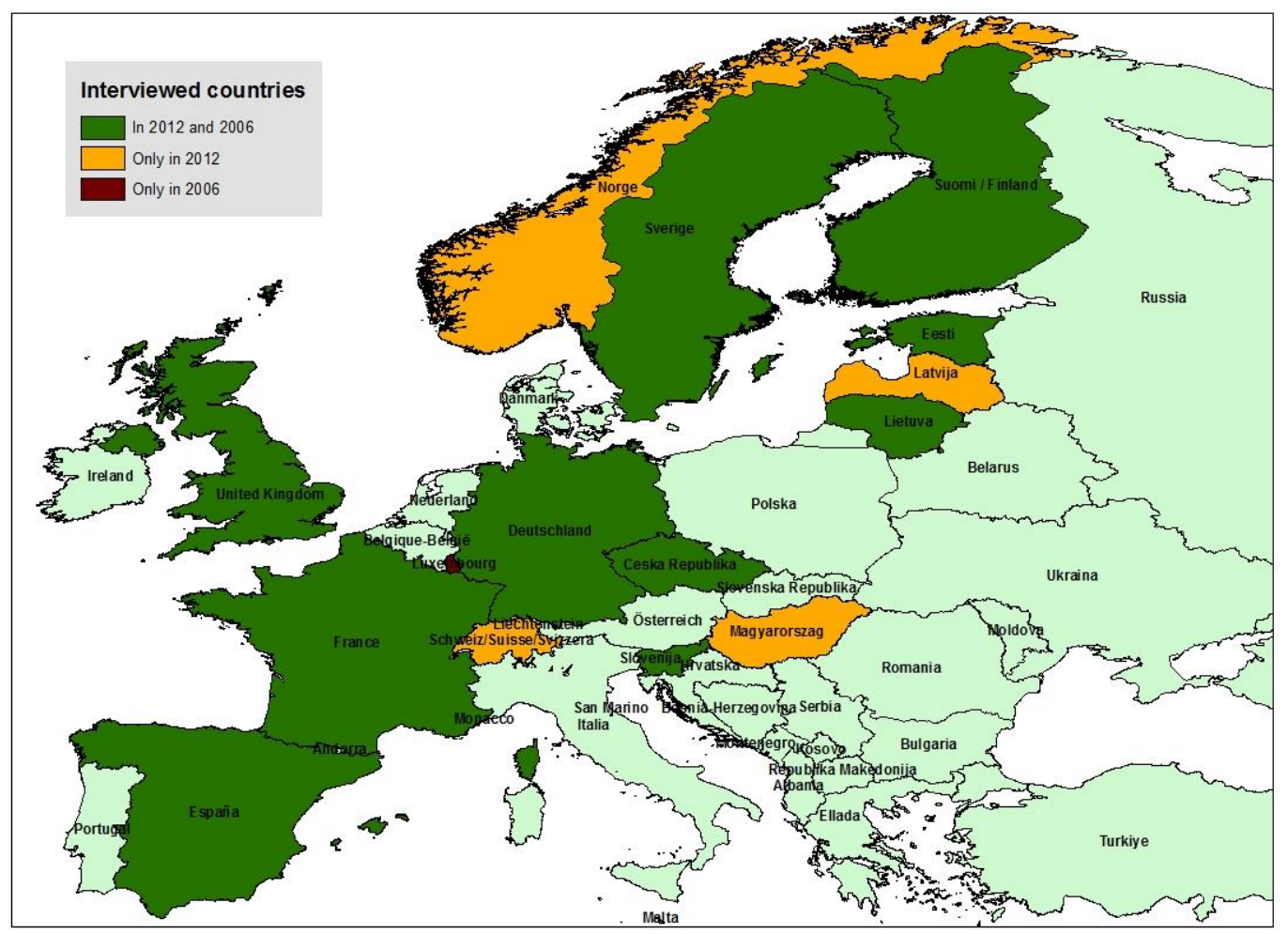

Figure 2. Countries that have responded to the survey in 2012 and /or 2006

The design of the questionnaire was structured in 30 questions, some of them in the way of multiple choice answers (Neuman, 2009), but most of them open questions to gather opinions besides of facts (Bryman, 2004), following the guidelines in the design of the questionnaire from Fazio and Gilbert (2000). Thematically the questionnaire was divided into five parts according to Corbett (2006): general info, goals and strategy, target groups and alliances, communication content (message), communication tools.

It can be considered as a shortage of this research the missing part of the information that might come from a face to face interview because many topics can be hidden; but otherwise the survey was based on open questions mainly. 


\section{2.- Methods}

The EU has shown a growing interest in comparisons between member states, particularly in the social policy area, often as a means of evaluating the solutions adopted for dealing with common problems or to assess the transferability of policies. Comparative research methods have long been used in cross-cultural studies to identify, analyze and explain similarities and differences across societies.

Besides in the case of this study a temporary analysis is added, doubling the value of the results, as it can be analyzed the evolution of the strategies during last 6 years, and at the same time validate the previous answers.

The methodology may combine surveys, secondary analyses of national data, and also personal observation and an interpretation of the findings in relation to their wider social contexts (Hantrais, 1995) (Frankfort-Nachmias and Nachmias, 1999).

The surveys'questionnaires follow the guidelines for planning environmental communications from Jurin, R. et al. (2010), and the following results are presented according to structured items.

\section{6.- Results: survey findings}

Table 1. Abbreviations used in the graphs for the countries

\begin{tabular}{|c|c|c|c|}
\hline CZ & Czech Republic & LT & Lithuania \\
\hline EE & Estonia & LU & Luxembourg \\
\hline FI & Finland & SI & Slovenia \\
\hline FR & France & ES & Spain \\
\hline DE & Germany & UK & United Kingdom \\
\hline SE & Sweden & LV & Latvia \\
\hline NO & Norway & HU & Hungary \\
\hline SW & Switzerland & & \\
\hline
\end{tabular}

\subsection{Organization}

In 2006 the person in charge of communication was mostly defined as a person specifically trained in communication (Figure 3). In about half of the countries, this person was a forester, but specifically trained for this purpose in most cases. A remarkable shift is happening towards hiring a media professional (journalist or similar); whilst in 2006 only Slovenia had one, in 2012 higher proportion of countries have hired a media professional. 




Figure 3. Person in charge of the communication

A media professional might be more skilled to drive grassroots actions by reaching wide public, whilst president/directors might have the profiles of more high-level connections to decision-makers to exercise treetops lobbying.

In 2006 the budget spent on communication affairs averaged less than $5000 € /$ year or between 10 000 and $15000 € /$ year in most countries. This meant in most cases between 10 and $20 \%$ of the amount of the total budget. In 2012 the average on budget for communication issues has decreased, with most countries now lower than $10 \%$. The two exceptions are Germany and France which expend between 20 and $30 \%$ of their budgets in communication (more than $25000 € /$ year). 


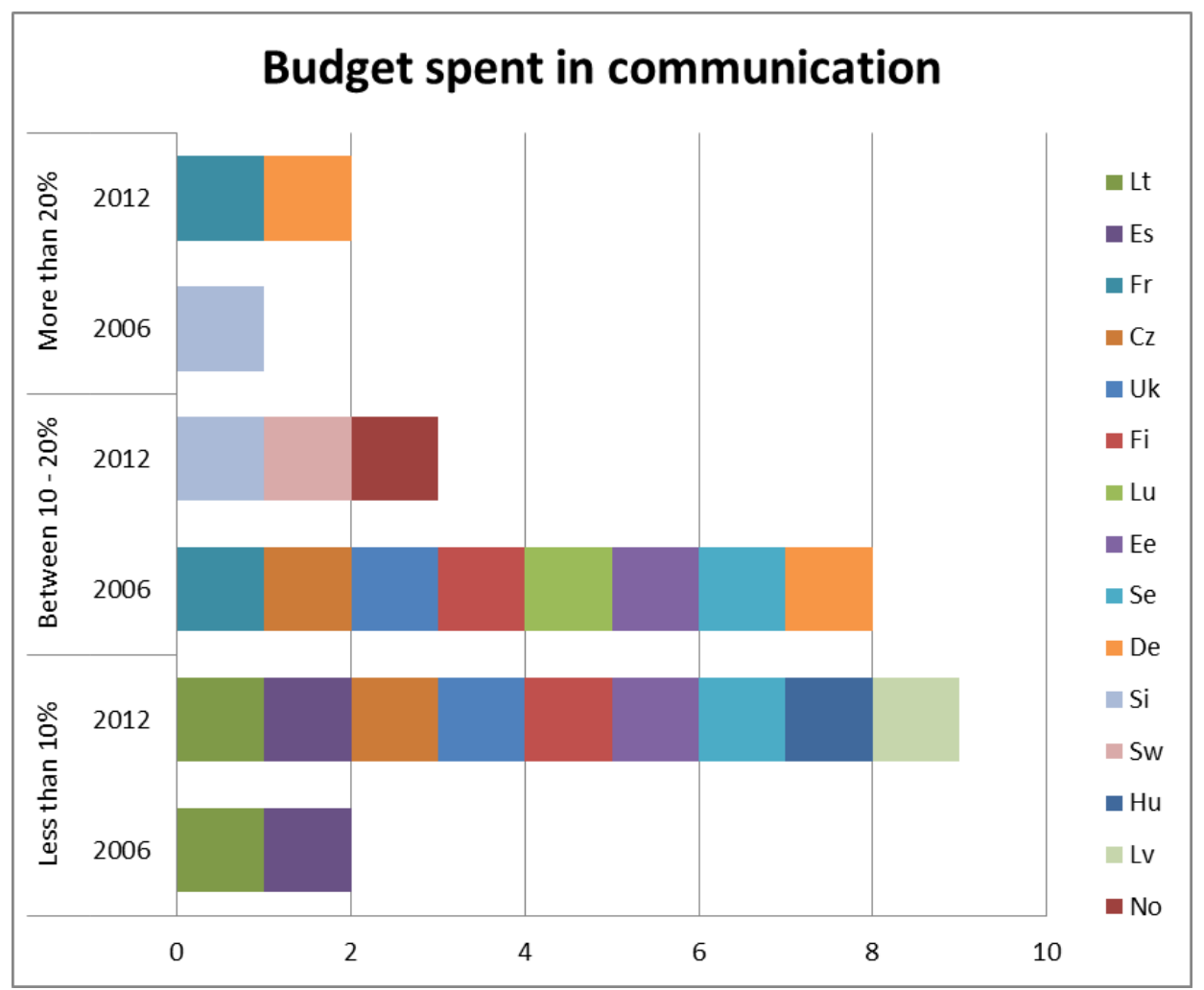

Figure 4. Budget spent in communication

\subsection{Objectives and strategies}

In 2006, most countries' FOAs didn't have a communication strategy at all, whereas in 2012 most of the countries have it (except Estonia, Spain and Germany) (Figure 5). However, in 2012 as in 2006, only half of the countries have it in a written form. When they had a strategy only four countries out of eleven (in 2006) would classify their lobbying actions as anticipatory (acting beforehand), which shows that most countries have adopted a more active attitude towards communication and lobbying in 2012 in comparison with 2006, with no country classifying it nowadays just as passive (Figure 6). Otherwise concerning the term (Figure 7) it has shifted to shorter term, or at least a combination with long term (fifty-fifty). Another progress in 2012 is that the regional organizations are coordinated with the national level strategies for communication for all the countries. 


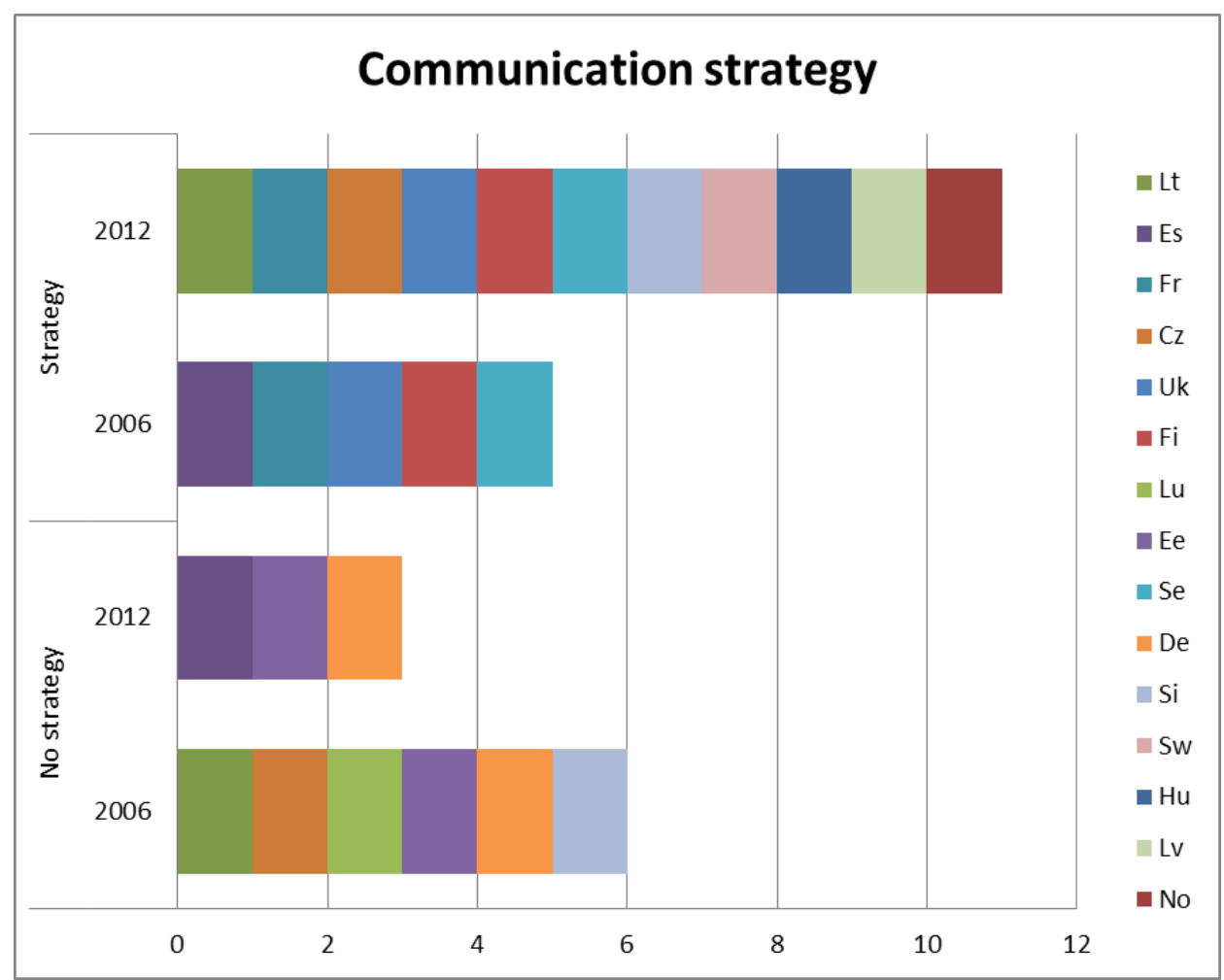

Figure 5. Communication strategy

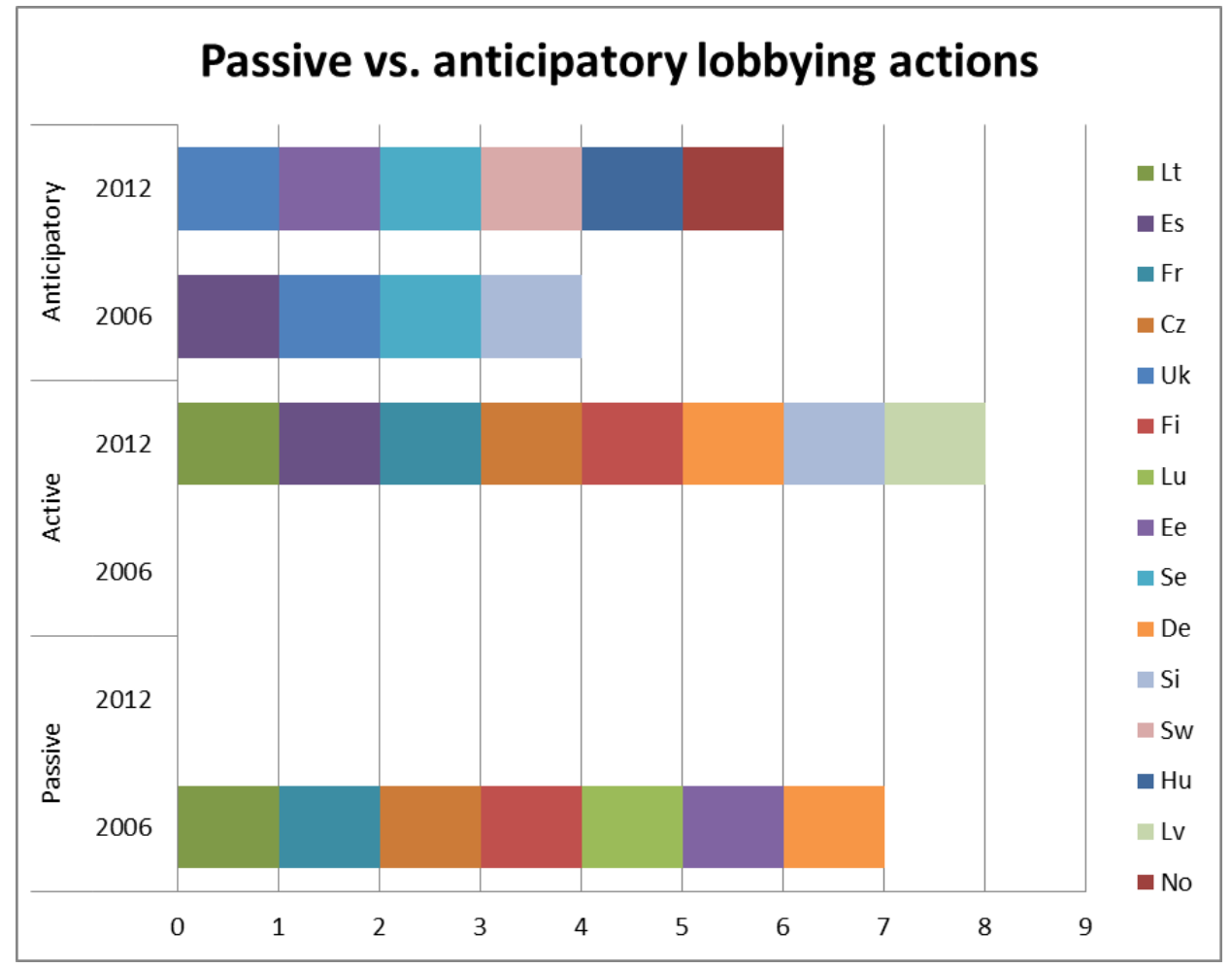

Figure 6. Passive vs. anticipatory lobbying actions 


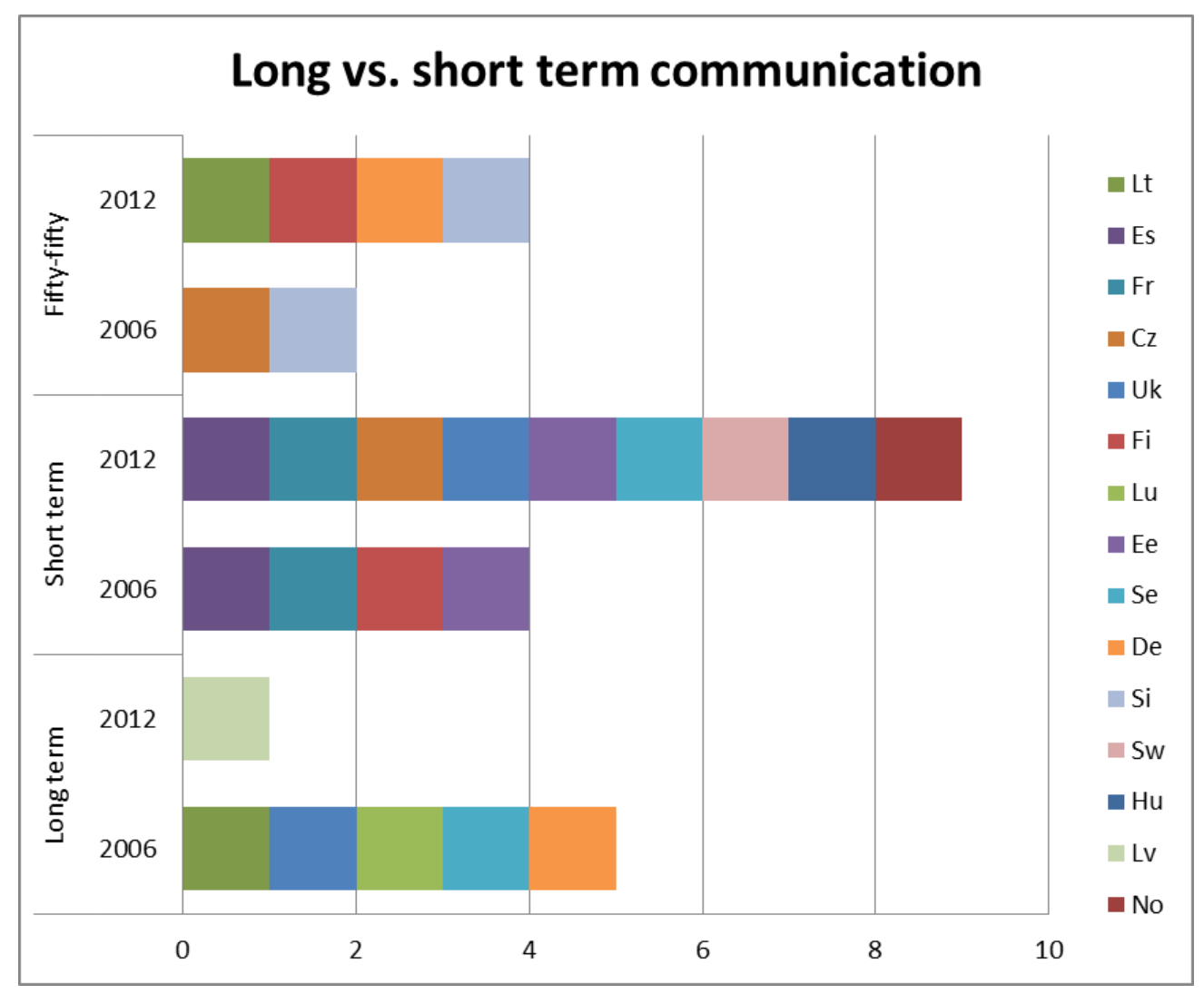

Figure 7. Long vs. short term communication

Regarding the main goals for communication established by the different countries, they are focused in some countries mainly towards the promotion of wood for the economic benefit of the forest owners, whilst in many other countries the main effort in communication is to improve the image of the forest sector in general or the image of the forest management carried out by the private owners. These goals have not changed along the years, however new goals have arisen in 2012 concerning economic issues (Table 2).

Table 2. Some examples of communication goals in 2006 and 2012 (Q3)

\begin{tabular}{|c|c|}
\hline 2006 & the interests of forest owners and to support cooperation among them \\
\hline & To develop wood consumption \\
\hline & $\begin{array}{l}\text { To improve the image of forest sector presenting services enabled by forests (water, leisure, } \\
\text { biodiversity...) }\end{array}$ \\
\hline & $\begin{array}{l}\text { To show to the public the necessity of forest management to guarantee multifunctionality and } \\
\text { sustainability }\end{array}$ \\
\hline & $\begin{array}{l}\text { To persuade the public that private forests are managed better or at least as well as the state } \\
\text { forests }\end{array}$ \\
\hline & To guarantee access to the media to represent and defend the sector's legitimate interests \\
\hline & $\begin{array}{l}\text { To raise awareness of the importance of the forestry sector and forestry activity in economic, } \\
\text { social and environmental terms }\end{array}$ \\
\hline & $\begin{array}{l}\text { To allow the exchange of information between forest owners and the Ministry of } \\
\text { Environment/Agriculture }\end{array}$ \\
\hline
\end{tabular}




\begin{tabular}{|l|l|}
\hline 2012 & To support the political work by informing relevant decision-makers \\
\cline { 2 - 3 } & To create new work places in the forest \\
\hline \multirow{y}{*}{$\begin{array}{l}\text { To inform/influence/raise awareness of media, partners, ministry, politicians about our } \\
\text { activities and problems so, that forest policy will enable sustainable and profitable forestry }\end{array}$} \\
\cline { 2 - 3 } & To spread information about timber market to forest owners to help their decision making \\
\cline { 2 - 3 } & To be considered representing interest of family forest owners in the country \\
\cline { 2 - 3 } & To defend (a better) forest tax system \\
\cline { 2 - 3 } & To promote a positive and appropriate image of Family Forestry sustainable management \\
\hline & To communicate towards member organizations about various policy developments and events \\
\hline & To give the politicians enough information, so they can take good decisions for forestry \\
\cline { 2 - 3 } & To inform the public, and secure a broad support for an active forestry sector \\
\cline { 2 - 3 } & To push for an optimal added value for the natural resource wood \\
\hline
\end{tabular}

It is convenient not to mix up both, goals and messages, because goals remain at the strategic level, as the final goal of what is the perception that it is wished people to bear in mind for the long term.

\subsection{Target}

Concerning the target groups of the lobbying actions, the direct public relations activities take place mainly towards the Ministries where forest responsibilities are located (Agriculture or the Environment (or both) depending on the country). They also take action towards politicians (both parliamentarians and decision-makers). Only one country had no priorities with respect to politicians in 2006, and only couple of countries had children/youth among their top targets (to become grassroots approach). However in 2012 all countries point the importance to address politicians. And already many of them give importance to other targets as children/youth, wood and paper industry, etc. As novelty, several countries focus on the relevance to address journalists and mass media, because of their power in communication. This is the basic tool for a shift and/or reinforcement of the grassroots strategy, by reaching the general public through mass media.

When asked 'with which other would you like to improve your communication', for some FOA the answer in 2006 was shared between ENGOs, the wood industry and schools, users of forests, and companies. In 2012 all same groups have remained the most quoted, otherwise ENGOs have diminished, and for example other groups have appeared, as hunters, mass media, or European institutions.

When asked about their alliances with other groups, in general the answer is positive, FOA have different alliances depending on the subject they are lobbying (jobs with trade unions, sustainable views with ENGOs, etc).

Due to their relevance, it was asked also about specific alliances with scientists, and the main partners were found to be forest research institutes and universities. Only Finland funded its own research in 2006. In 2012 more countries established now strong ties with research (Fi, Fr, Uk, Se, $\mathrm{Ee}, \mathrm{De}, \mathrm{No})$ as the rest seems that they have weaker partnership. 


\subsection{Messages}

About the messages from the forest owners associations towards the society still most countries focus on explaining how wood use is environmentally friendly, and thus forests need to be harvested and managed actively. There is a wide range of messages directed by the organizations in the different countries (Table 3) which shows that the current needs in different countries are not the same. Besides to communicate that most of forests in Europe are private owned and also that those provide externalities and benefits for the whole society. But also in most countries the message is not on product interests but on defending the interests of morals and ideas. These bases have remained the same in 2006 and 2012, however new messages have popped up in 2012 concerning climate change, biomass or green economy.

Table 3. Messages from the forest owners associations to society in 2006 and in 2012 (Q17)

\begin{tabular}{|c|c|}
\hline \multirow{14}{*}{$\begin{array}{l}2006 \\
\& \\
2012\end{array}$} & The forest is not only nature, it is maintained by forest owners. \\
\hline & Private forest ownership can be as efficient and well managed as forestry in the public sector. \\
\hline & $\begin{array}{l}\text { Being sustainable, family forestry must be profitable. Thus, the social and environmental role of foresters } \\
\text { and forestry needs to be compensated to reach the necessary balance between costs and profits. }\end{array}$ \\
\hline & Private ownership is the biggest group of forest owners (62\%), held by people like you and me. \\
\hline & Family forest owners are the key actors and the best partners to develop forestry and environmental policies. \\
\hline & $\begin{array}{l}\text { The forests don't belong to the visitors (hunters, mushroom-pickers, bikers, NGOs, etc ), each forest has an } \\
\text { owner, who is obliged to care about it. }\end{array}$ \\
\hline & The long-term private ownership of forests is a guarantee of sustainable forest management. \\
\hline & $\begin{array}{l}\text { A forest owner works for him but also for the future generations and the society. Therefore, general public } \\
\text { and decision-makers should support active management of private forests. }\end{array}$ \\
\hline & $\begin{array}{l}\text { If there are restrictions on forest management for the benefit of general public and environment, then it } \\
\text { should be properly compensated to forest owner. }\end{array}$ \\
\hline & $\begin{array}{l}\text { Forest ownership is often linked to family traditions and it is a way of living. Forest owners are one of the } \\
\text { important actors in sustaining our rural areas. }\end{array}$ \\
\hline & Forest ownership is about social, economic and environmental values that the forest owners hold. \\
\hline & $\begin{array}{l}\text { Sustainable forest management in private forests in an inter-generational contract based on long term } \\
\text { planning and responsible resource management. }\end{array}$ \\
\hline & $\begin{array}{l}\text { Wood is growing each year more than it is harvested. Wood products are very diverse and renewable, and } \\
\text { forest owners are able to produce them. }\end{array}$ \\
\hline & Multifunctional forestry provides a wide range of goods and services to society. \\
\hline \multirow{6}{*}{$\begin{array}{l}\text { New } \\
\text { in } \\
2012\end{array}$} & The forest management by promoting the use of wood products, contributes to mitigate climate change. \\
\hline & Use wood wisely - don't burn it in large-scale generators. \\
\hline & $\begin{array}{l}\text { An active forest owner secures healthy forests, biodiversity and creates a lot of biomass, which can be used } \\
\text { for the good of the society. }\end{array}$ \\
\hline & $\begin{array}{l}\text { Timber/biomass can be "the new oil". Everything you make of oil, you can also make of biomass. Biomass } \\
\text { is a very environmental friendly material, and should be used to a larger extent. }\end{array}$ \\
\hline & Creating a favorable environment -through politics- to achieve an optimal value in forestry. \\
\hline & \\
\hline
\end{tabular}

\subsection{Channel}


On the subject of channel, still face to face is the most preferred way to communicate, same in 2006 than in 2012 (Table 4), but it can be noticed a relevant place, for channels which reaches lot of people at the same time (e.g. websites, newsletters) are seen as the most powerful and cost-effective tools. Even so, the channels which involve education and high a commitment with interested people are becoming strategically very important, because they can be the seed which spreads the new ideas of change (e.g. publications, exhibitions).

Table 4. Most preferred channel by FOA to communicate and lobby

\begin{tabular}{|l|l|l|l|l|}
\hline & \multicolumn{2}{|c|}{2006} & \multicolumn{2}{c|}{ 2012 } \\
\hline & In first place & In second place & In first place & In second place \\
\hline Advertising & & Fr & & \\
\hline Face to face & De, $\mathrm{Lu}, \mathrm{Es}, \mathrm{Fi}, \mathrm{Fr}$ & & $\begin{array}{l}\text { Fi, Si, Fr, Uk, } \\
\text { Ee, No, } \mathrm{De}, \mathrm{Es}\end{array}$ & $\mathrm{Lt}$, \\
\hline Website & $\mathrm{Lu}, \mathrm{Fi}$ & & $\mathrm{Lt}, \mathrm{Sw}, \mathrm{Hu}$ & $\mathrm{No}, \mathrm{De}$ \\
\hline Newsletters & $\mathrm{Si}, \mathrm{Se}$ & $\mathrm{Es}, \mathrm{Fi}$ & $\mathrm{Cz}$, & $\mathrm{Hu}, \mathrm{Es}$ \\
\hline Publications & & $\mathrm{De}, \mathrm{Se}$ & $\mathrm{Lv}$ & \\
\hline Exhibitions & & $\mathrm{Uk}$ & & $\mathrm{Cz}, \mathrm{Uk}$ \\
\hline Presentations/Forums & $\mathrm{Uk}$ & & $\mathrm{Se}$ & $\mathrm{Fi}, \mathrm{Fr}, \mathrm{Sw}, \mathrm{Lv}, \mathrm{Ee}$, \\
\hline Educational activities & $\mathrm{Lt}$ & $\mathrm{Fi}$ & & $\mathrm{Si}, \mathrm{Se}$ \\
\hline
\end{tabular}

In 2012 almost all countries keep permanent ties with mass media, whereas in 2006 still few countries affirmed that they contact the mass media only in the case of a crisis, lacking permanent communication channels most of them. This again reflects the need and the wish for a stronger grassroots support in order to justify their treetops actions.

\subsection{Coalitions with other stakeholders}

When asked to the FOAs with which groups do you keep in touch regularly, all of them answered that with agricultural organizations as well as with the wood and paper associations. However the discrepancy is on ENGOs where not all countries keep in touch regularly, reflecting the degree of conflictivity with such associations, and probably the lack of shared values in some countries.

\subsection{Campaign techniques}

Campaign techniques (grassroots), such as the massive sending of postcards or emails, which are widely applied by ENGOs (Corbette, 2006), were not common in FOA in 2006, and only half of them used such techniques, but in 2012 thanks to the facilities of the email, increasing number of countries use massive emailing of newsletters on specific campaigns. In some exceptional occasions some countries have used also more similar to "campaign techniques" as the case of demonstrations (De in 2006), promotion of the wood certification systems (Lu in 2006) delivering trees to politicians with a message (Fr in 2012), etc.

\subsection{Evaluation}


In 2006 as still in 2012, most of the FOAs don't have a proper internal system for evaluating the results of their communication results; just follow up of mass media coverage, but not in systematic way. Even some countries which had some kind of evaluation system in 2006, don't implement it anymore at 2012 (such as $\mathrm{Si}$, Uk, Fr). Three countries which nowadays evaluate their communication activities proceed in quite different ways: media-cover monitoring daily, imagesurveys every second year, case analysis in crisis situations (Finland); checking public attitudes by questionnaires (Sweden); quantitative methods for evaluating communication activities as well as qualitative evaluation as for hot topics on the political agenda and the relevant decisions taken (Latvia).

\section{7.- Discussion and conclusions}

Strategy. A written communication strategy should appear as the first priority to be set for every country, in order to design a tailor-made frame of goals-messages-channels for every different receiver of the communication. It is not scientific evidence that a written strategy works better, but at least a written document might have passed a consensus phase among their creators. It may be helpful to follow a stable direction, to develop all aspects and with all the needed alliances with other stakeholders. In 2006 few countries had a communication strategy whereas in 2012 most countries (except three) say to have one which represents a great progress; however few countries have it written. Among the three countries that don't have a strategy, it seems specifically serious for Germany, because they spend a large budget on communication. Overall, to have a strategy seems to be efficient as it has shifted in this period towards more active communication and towards more balanced short-term and long-term goals in their strategies. Somewhat strange however is that the tendency goes towards short term strategies. CEPF performs an important role in on coordination and joint effort to strength communications strategies in every country; however it seems that there is still much room for improvement.

One of the most comprehensive communications strategy guidelines in Europe, is the one drafted by the Forest Communications Network (UNECE, 2013), which should become the framework for the FOA communications strategies. It encourages writing a strategy for forest organizations.

Organization. Regarding the profile of the person in charge of communication/lobbying, it can be stated that the degree of professionalism might be enough, but it would be advisable to have the support of a journalist, which in fact has been the case in 2012 in 5 countries already. An economic constrain may be the case for not having more, as the share of the total budget assigned to communication looks in general to be quite modest (lower than $10 \%$ ), in an average of about 10000

$€ /$ year. These data on the total budget, has to be considered in accordance of relative area of private forests and/or its importance (it can have been affected for the international economic crisis). 
In the hiring of a mass media professional can be noticed a relationship on the richest/most developed countries. On high expenditure of budget, the two big European countries (Germany and France) have the lead. However in other issues as the three countries which have no communication strategy (Germany, Spain and Estonia) no grouping factor is identified. Therefore other hypothesis on potential factors in the grouping of countries like the size of the country, ownership distribution, forest cover share, development stadium, cultural background, etc have not been identified to be influencing in any grouping of responses. It hasn't been noticed any geographical grouping in countries concerning any of the answers, as every country has its own way.

There is a wide variety of FOAs in Europe, which in spite of having more or less capacity due to the different importance of the forest sector in each country, are able to perform communication actions with different degree of success. Otherwise in general, from 2006 to 2012 it has been found positive improvement in most of the researched issues.

Organization evolves along the time for every FOA, and whenever the staff has good skills for communication and a clear strategy on how to do it, might be more important the personal links to reach and influence target people, than the techniques themselves, when talking on treetops.

In a preliminary website review it has been noticed that many forest-based industry organizations on a national or European level have experts fully dedicated to communication matters. All the big forest companies in Europe (StoraEnso, UPM, SCA...) have Departments of corporate communications. This is not the case among the rest of the forestry stakeholders. Otherwise you have to consider the different size. If we compare with the main ENGOs in Europe, those have between 2 (Greenpeace, 2013) and 5 (WWF, 2013) who are specialized professionals dedicated to the communications, besides of the numerous volunteers. In Greenpeace' financial statements for 2012, communication accounted $14 \%$ of their budget (Greenpeace, 2012).

Despite that each country and even region inside a country will keep their own objectives, as forests and forestry is very diverse for the different countries; the EU forestry communication strategy (European Commission, 2011) fixes four general common goals shared among all forest sector that might be common baseline for all stakeholders. These goals refer to the need of sustainable management, how forests provide products and services, the threats and challenges of forests, and to increase the use of wood as climate friendly materials and renewable energy sources.

Targets. Politicians almost always find support for their decisions from the high level civil servants to make their decisions based on technical evidence. High level civil servants work at the heart of the "core executive", which develop and make government policy; this is where power lies (Heywood, A. 2011). Therefore it could be assured that it is much more effective to lobby the bureaucrats than the politicians. In forestry this would mean lobbying the highly representative officers (which sometimes they are very ideological and long lasting with decades in service) in the Ministries. Even though, pressure is more efficient with politicians. 
Nevertheless, those politicians and decision-makers use to weight the lobbing strength by the number of people (regarded as voters) that they represent. Consequently, a main target for a FOA has to be permanently to gather more and more forest owners as members, until reach ideally the $100 \%$. And at the same time, activate as much as possible the 16 million European forest owners as active ones in the public debate. As comparison, Greenpeace has around 3 million financial supporters (members) Worldwide from where around 2 million are located in Europe.

On the other hand, in order to change the long term perceptions of the society towards forests and forestry, it might be needed to target society in general and children/young in particular, which is not being the priority among FOAs' grassroots strategies.

Messages. Forests mean different things to different people and this can create conflicts of interest resulting in mixed and confusing messages (Krott, M. 2000). Messages evolve with the development of the forest sector and the new realities (e.g. biomass, climate change). In general the messages of the FOAs are in line with the four general messages suggested by the Forest Communications Network (UNECE, 2013). Besides, none of these messages are opposed by any campaign from the main ENGOs in Europe.

Over the last years, communication channels are changing fast, and internet above of all is having a great influence on creating and mobilizing public opinion. Social networks, as well as online short videos, are nowadays an easy tool for spreading messages. However whilst main ENGOs are present in the social networks, forest owners are not yet there. Involving the decision-makers in forums of discussion has been proven to be a very effective way to influence them. Under the best circumstances, the broadest range of communication channels must be used, as each channel might be its best for reaching each different target group.

Campaign techniques have plenty of room for improvement, and such techniques employed by ENGOs have been proved to be efficient ways to get mass media attention and therefore public opinion in the focus.

Both approaches, treetops and grassroots are exercised by the FOAs, as a combined strategy, pointing direct actions towards decision-makers at the same time that they target the public awareness on forestry benefits for a long term support from the society. However the potential power of the millions of forest owners to perform grassroots actions might still be underutilized.

Common forums and specific initiatives as for example the UNECE-FAO Forest Communicators Network (UNECE, 2013), which aims exchange experience in order to identify the best practices, might help in giving homogeneity on strategies and messages, as well as improving the professionalization of forest stakeholders wishing to communicate and lobbying. These professional forums constitute the political learning which drives to the policy advance and change. 
Evaluation on social change is always a difficult long-term processes, and the only way is by periodical public opinion polls. Otherwise influence in national or European processes as for example in any review of the Common Agricultural Policy, can be easy to monitorize when specific measures have been proposed to be included. Nevertheless, some countries might serve as a benchmarking for the rest of the FOAs to improve their systems.

Communication is a social science and therefore it does not have same results even under same condition, because people always differ. Therefore the process of evaluation and follow-up should be the most important part in a communications strategy even if to measure it turns to be so difficult.

Coalitions and competition with other stakeholders. The Advocacy Coalition Framework (ACF) (Sotirov and Memmler, 2012) is applied to policy debates, where often conflicts appear due to different stakeholders with different and opposite values that they want to lobby in order to meet their goals.

From the perspective of the Advocacy Coalition Framework (ACF) (Sotirov and Memmler, 2012) it can be said that the different FOAs might share the core beliefs and therefore there is an ideological link. Therefore from the perspective of the new model of effective lobbying strategies in the case of the FOAs, it hasn't been found as an important factor the competition with other sectors, which will come in this case as a third factor in importance instead than as a second factor as defined in the model. However it has been noticed that the national interests towards more or less productive forestry states the different alliances in their coalitions, especially with ENGOs. 


\section{8.- Recommendations}

Only forest owners are the main and first responsible for the management of their lands. And consequently politicians hardly implement anything in forestry without their involvement. They are a relevant forest stakeholder, who can be face-to-face with wood and paper companies, because they form the bases of the forest value chain, by having the control of the raw material supply. Therefore, actually if they are well organized and communicate adequately, they might reach considerable bargain power.

There are some other lessons learned from this research: communications strategies at FOAs could and should be improved, and the best way is probably to follow a strategy, with all its elements properly developed (objectives, messages, targets, channels, evaluation...). The joint effort with communication/mass media professionals would always turn into a more successful result. Goals have to be identified at short as well as long term, wide variety of channels should be used, messages have to be simple and clear, and collaboration with others organizations (agriculture, wood construction, etc) has to be enhanced. Examples from more experienced organizations and sectors in communication shall be benchmarked, and knowledge and experiences shall be transferred from one country to another.

Further research is needed into public perception of forests and forestry, which might help to define communication strategies. Finland already has a long tradition of these studies (SMY, 2012) and it is expected that more countries will follow. Another research subject shall be to study the techniques for the grassroots strategies that ENGOs apply successfully, to learn from their broader experience in mobilizing people and thus take advantage of the critical mass of 16 million forest owners spread around Europe.

\section{9.- Acknowledgements}

The authors are grateful to all the Forest Owners Associations that have participated in this research study by answering the questionnaires both in 2006 and again in 2012.

\section{0.- References}

Aasetre, J., 2006. Perceptions of communication in Norwegian forest management. Forest Policy and Economics. Volume 8, issue 1.

Bach, D. and Unruh, G., 2005. Lobbying. Instituto de Empresa. Madrid, Spain.

Berlo, D. K. 1960. The process of communication. New York, New York: Holt, Rinehart, \& Winston. 
Buttoud, G. and Samyn, JM., 1999. Politique et planification forestière. Guide pour la formulation et l'élaboration. Intercooperation. Berne. 87 p. (in French). France.

Bryman, A., 2004. Social research methods. Ed. Oxfod University press. New York, USA.

CEPF, 2009 Confederation of European Forest Owners. Available from http://www.cepf-eu.org/ [Accessed June 2014].

Corbett, J., 2006. Communicating Nature. How we create and understand environmental messages. Island Press, London, UK.

COST Action E-19., 2004. Forests for the future. National forest programmes in Europe. UK.

Cottle, M. Howard, T. 2012. Conflict management and community support for conservation in the Northern Forest: Case studies from Maine. Journal of Forest Policy and Economics. Volume 20, July 2012, Pages 66-71.

Cox, R., 2006. Environmental Communication and the public sphere. Sage Publications. California, USA.

Craig, R. 1999. Communication Theory as a Field. Blackwell Publishing Ltd.; International Communication Association.

Dominguez, G., 2008. Understanding Forest Owners in a Mediterranean Context. Constructing theory through descriptive and interpretational analysis. Dissertation. Albert-Ludwigs University. Freiburg, Germany.

European Commission., 2011. EU Forest Communication Strategy. DG Agriculture and Rural Development. Available from http://ec.europa.eu/agriculture/fore/publi/communicationstrategy_en.pdf [Accessed June 2014].

European Commission., 2009. Shaping forest communication in the European Union: public perceptions of forests and forestry. DG Agriculture and Rural Development.

European Commission., 2007. Forestry statistics. Brussels, Belgium.

Fabra-Crespo, M et al. 2012. Public perception on forestry issues in the Region of Valencia (Eastern Spain): diverging from policy makers?. Journal of Forest Systems 2012 21(1): 99-110

FAO, 2011. State of Europe's forests 2011. Status \& trends in Sustainable Forest Management in Europe. UNECE, Geneva, Switzerland.

FAO, 2010. Private forest ownership in Europe. Geneva Timber and forest study paper n 26. United Nations.

Fazio, J. and Gilbert, D., 2000. Public Relations and Communications for Natural Resource Managers 420 pages; softcover. Kendall/Hunt Publishing Company. Dubuque, Iowa, USA.

Forest Europe, 2011. State of Europe's Forests 2011. Status and trends in sustainable forest management in Europe.

Ed. United

Nations. 
http://www.foresteurope.org/documentos/State_of_Europes_Forests_2011_Report_Revis ed_November_2011.pdf [Accessed June 2014].

Frankfort-Nachmias, C. and Nachmias, D., 1999. Research methods in the social sciences. Ed. Worth publishers.

Ghai, D. and Vivian, J.M., 1992. Grassroots environmental action: people's participation in sustainable development. Ed. Routledge.

Glück, P. et al., 2010. The preconditions for the formation of private forest owners' interest associations in the Western Balkan Region. Journal of forest policy and economics. Volume 12, issue 4, pp. $250-263$.

Greenpeace, 2013. Available from http://www.greenpeace.org/eu-unit/en/about/staff/ [Accessed June 2014].

Greenpeace, 2012. Annual report 2012. Greenpeace International. Available from: http://www.greenpeace.org/international/Global/international/publications/greenpeace/20 13/GPI-AnnualReport2012.pdf [Accessed June 2014]

Greenwood J. and ThomasC. 1998. Regulating Lobbying in the Western World, 51 PARLIAMENTARY AFF. 487, 487.

Hantrais, L., 1995. Comparative research methods. In: Social research update. Issue 13, summer 1995. Department of Sociology, University of Surrey, Surrey, UK.

Heywood, A., 2011. Essentials of UK politics. Ed. Palgrave Macmillan.

Hyttinen, P., 2001. Prospects for small-scale forestry in Europe. In Niskanen, A \& Väyrynen, J (eds) Economic sustainability of small-scale forestry. EFI Proceedings N 36, Joensuu, Finland.

IFFA - International Family Forest Alliance. Available from http://www.familyforestry.net/ [Accessed September 2013].

Jaatinen, M. 1998. Lobbying for conflict accommodation - a contingency model. Corporate communications - An international journal, Vol. 3, No 1, March/April, 23-42.

Jaatinen M. 1999. Lobbying political issues. A contingency model of effective lobbying strategies. Inforviestintä. Helsingin yliopisto verkkojulkaisut, Helsinki.

Janse, G., 2007. Communication in forest policy decision-making in Europe: a study on communication processes between policy, science and the public. Dissertationes Forestales 48. Faculty of Forest Sciences. University of Joensuu, Joensuu, Finland.

Jurin, R. et al., 2010. Environmental communication. Skills and principles for natural resource managers, scientists and engineers. Second edition. Springer. 
Kittredge, D., 2005. The cooperation of private forest owners on scales larger than one individual property: international examples and potential application in the United States. Forest Policy and Economics, Volume 7, Issue 4, May 2005,pp. 671-688.

Krott, M., 2000. Voicing interests and concerns of forestry. Forest Policy and Economics. Volume 1 , issues 3-4.

Mendes, A. et al., 2006. Forest owners' organizations across Europe: similarities and differences. In: Niskanen, A. (edt.) Issues affecting enterprise development in the forest sector in Europe. Research Notes 169. Faculty of forestry. University of Joensuu. Finland.

Moscovici, S. et al. eds, 1994. Minority influence. Ed. Nelson-Hall. Chicago, USA.

Neuman, L., 2009. Social research methods: qualitative and quantitative approaches. Ed. Allyn \& Bacon. $7^{\text {th }}$ edition.

Ní Dhubháin, A. et al., 2007. The values and objectives of private forest owners and their influence on forestry behaviour: the implications for entrepreneurship. Small-Scale Forestry 6(4): pp. 347-357.

Novais, A and Canadas MJ. 2010. Understanding the management logic of private forest owners: a new approach. Journal of Forest Policy and Economics. Volume 12, issue 3.

Ok, K., 2005. Idea marketing in forestry: some implications from the Turkish forestry experience. Forest Policy and Economics. Volume 7, Issue 4, May 2005, pp. 493-500.

Pollumae, P. Korjus H. Paluots, T. 2014. Management motives of Estonian private forest owners. Forest Policy and Economics, Volume 42.

Primmer, E. Kyllönen, S. 2006. Goals for public participation implied by sustainable development, and the preparatory process of the Finnish National Forest Programme. Journal of Forest Policy and Economics. Volume 8, Issue 8, November 2006, Pages 838-853.

Saarikoski, H. et al. 2010. Public participation in practice - assessing public participation in the preparation of regional forest programs in Northern Finland. Forest Policy and Economics. Volume 12, issue 5.

Serbruyns, I. and Luyssaert, S., 2006. Acceptance of sticks, carrots and sermons as policy instruments for directing private forest management. Forest Policy and Economics, Volume 9, Issue 3, 1 December 2006, pp. 285-296.

SMY, 2012. Metsä ja puu (Forest and Timber) opinion poll. Finnish Forest Association. Available from http://www.smy.fi/smy/smyeng.nsf/allbyid/5299BE6F4BDD354FC225717A003A857D? Opendocument [Accessed June 2014]. 
Sotirov, M. Memmler, M. 2012. The Advocacy Coalition Framework in natural resource policy studies - Recent experiences and further prospects. Journal of Forest Policy and Economics. Volume 16, March 2012, Pages 51-64.

Stordal, S., 2004. Efficient timber pricing and purchasing behavior in forest owners'associations. Journal of forest economics. Volume 10, issue 3, pp. 135-147.

Tusinski, K., 2009. Finding connections between lobbying, public relations and advocacy. Public relations journal Vol.3, No. 3.

UNECE, 2013. Forest Communicators' Network. United Nations. http://www.unece.org/forests/information/fcn.html [Accessed September 2013].

Urquhart, J. and Courtney, P., 2011. Seeing the owner behind the trees: A typology of small-scale private woodland owners in England. Forest Policy and Economics, Volume 13, Issue 7, September 2011, Pages 535-544

WWF, 2013. Available from http://www.wwf.eu/media_centre/ [Accessed June 2014].

Weber, N. Christophersen, T. 2002. The influence of non-governmental organisations on the creation of Natura 2000 during the European Policy process. Journal of Forest Policy and Economics. Volume 4, Issue 1, May 2002, Pages 1-12.

Xifra, J., 1998. Lobbying. Cómo influir eficazmente en las decisiones de las instituciones públicas. Ed. Gestión 2000. Deusto, Spain.

Ziegenspeck, S., Härdter, U. and Schrami, U. 2004. Lifestyles of private forest owners as an indication of social change. Forest Policy and Economics, Volume 6, Issue 5, August 2004, Pages 447-458

Zimmermann, W. and Schmithüsen, F. eds., 2002. Legal Aspects of National Forest Programmes. Papers presented at the meeting of COST Action E19, Aberdeen, Scotland, March 2001. Chair Forest Policy and Forest Economics, Swiss Federal Institute of Technology, ETH, Zurich. Forest Science Contributions Volume 25,153 p., Switzerland. 
ANNEX 1 - QUESTIONNAIRE

\begin{tabular}{|l|l|}
\hline Name: & \\
\hline Organization: & \\
\hline Position: & \\
\hline
\end{tabular}

1.- Person in charge of the communication affaires

\begin{tabular}{|l|l|}
\hline & It is a specific person in charge of the communication affaires \\
\hline & It is the same who takes charge as president/director \\
\hline & We have the support of a media professional \\
\hline We have in our staff somebody trained for such purpose \\
\hline
\end{tabular}

Background of the person in charge of the communication:

\begin{tabular}{|l|l|}
\hline & Forester \\
\hline & Journalist \\
\hline & Political science expert \\
\hline & Other (which background) \\
\hline
\end{tabular}

2.- Budget assigned to communication issues (absolute value and percentage of the total budget)

\begin{tabular}{|l|l|}
\hline & Less than $5.000 € /$ year \\
\hline & $5.000 €-15.000 € /$ year \\
\hline & $15.000-25.000 € /$ year \\
\hline & More than $25.000 € /$ year \\
\hline
\end{tabular}

\begin{tabular}{|l|l|}
\hline & Less than $10 \%$ \\
\hline & $\mathbf{1 0}-\mathbf{2 0} \%$ \\
\hline & $\mathbf{2 0 - 3 0 \%}$ \\
\hline & More than $30 \%$ \\
\hline
\end{tabular}

3.- Do you have a communication strategy?

\begin{tabular}{|l|l|l|l|}
\hline & yes & & no \\
\hline
\end{tabular}

Do you have a written communication strategy? (if yes, please attach it to the answer)

\begin{tabular}{|l|l|l|l|}
\hline & yes & & no \\
\hline
\end{tabular}

Which are your communication goals? (List the most important ones)

4.- Do you have an annual "operational plan" where you define the priorities of your communication action?

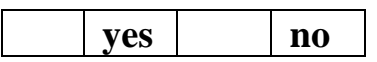

5.- Do the sub-member/regional organizations follow the same strategy?

\begin{tabular}{|l|l|l|l|}
\hline & yes & & no \\
\hline
\end{tabular}


6.- Which effect had the National Forest Programs on your communication action? It has created:

\begin{tabular}{|l|l|}
\hline & No effects at all \\
\hline & New participatory boards \\
\hline & Regular meetings among foresters \\
\hline & Forest forums \\
\hline & Other: \\
\hline
\end{tabular}

7.- Would you classify your lobbying actions as:

active (do you take action at the same time as the government is making a decision) passive (you take action when the government makes a decision) or anticipatory (you take action beforehand)?

8.- Tell to which of the following groups are directed the communication and public relations actions, and please indicate their importance to you $(1=$ least important, 10 is most important $)$ ?

\begin{tabular}{|l|l|l|}
\hline Industry & Wood \& paper & \\
\hline \multirow{5}{*}{ Iinistries } & Environment & \\
\hline & Agriculture & \\
\hline \multirow{5}{*}{ Society } & Other (specify) & \\
& Children & \\
\hline & Pre-university & \\
\hline & Families & \\
\hline Other (specify) & \\
\hline Politicians & Decision-makers & \\
\hline & Parliamentarians & \\
\hline Other (specify): & & \\
\hline Other (specify): & & \\
\hline
\end{tabular}

9.- With which groups do you keep in touch regularly and why?

\begin{tabular}{|l|l|}
\hline & Agricultural associations \\
\hline & $\begin{array}{l}\text { Wood \& paper industry } \\
\text { associations }\end{array}$ \\
\hline & Other (list them): \\
\hline & ENGOs \\
\hline & Trade Unions \\
\hline
\end{tabular}

With which other would you like to improve your communication and why?

\begin{tabular}{|l|l|}
\hline & \\
\hline & \\
\hline & \\
\hline & \\
\hline & \\
\hline
\end{tabular}

10.- Do you hold different alliances with other stakeholders depending on the subject you are lobbying? Explain: 
11.- Do you have communication with scientists, with a set of priorities? Do you try to enforce your credibility by partnerships with the academic world (or any other)? Explain:

12.- Do you keep special and continuous partnership with agricultural organizations? Explain:

13.- Could you indicate how much effort you spend on/how important you consider the following aspects of communication (e.g. $\mathrm{x} \% \mathrm{~A}, \mathrm{y} \% \mathrm{~B})$ ?

\begin{tabular}{|l|l|}
\hline $\begin{array}{l}\text { Long-term communication for increasing the level of knowledge in forest issues, } \\
\text { without a strong lobbying attempt for actual issues (e.g. communication with school } \\
\text { children and other target groups) }\end{array}$ \\
\hline Short-term communication about actual issues (e.g. campaigns) \\
\hline
\end{tabular}

14.- What is it that you want to communicate, what are your messages?

\begin{tabular}{|l|l|}
\hline Goal & Forest sector (internal) \\
\hline & \\
\hline & \\
\hline & \\
\hline
\end{tabular}

15.- What is it that you want to communicate, what are your messages? Think for instance of the following rough categories

\begin{tabular}{|l|l|}
\hline Goal & External from the forest sector \\
\hline & \\
\hline & \\
\hline & \\
\hline & \\
\hline
\end{tabular}

16.- Enunciate two messages that you would like to reach the society in your country in order to change their perceptions and values towards forestry

17.- Enunciate two messages that you would like to reach the society in your country in order to change their perceptions and values towards forest ownership

18.- Could you indicate the tools or groups of tools (and their strengths and weaknesses if applicable) you use to communicate with the outside world (partners, customers, "the public" etc.)? Please indicate by giving a 1 (=least important) to 10 (=most important). 


\begin{tabular}{|l|l|l|l|l|}
\hline $\begin{array}{l}1 \\
\text { to } \\
\mathbf{1 0}\end{array}$ & $\begin{array}{l}\text { Estimate the number } \\
\text { of times you have } \\
\text { appeared since } \\
\text { beginning of 2005 in: }\end{array}$ & $\begin{array}{l}\text { Strength } \\
\text { (Advantages) }\end{array}$ & $\begin{array}{l}\text { Weakness } \\
\text { (Diadvantages) }\end{array}$ \\
\hline & & Advertising & & \\
\hline & & Face to face & & \\
\hline & Website & & \\
\hline & & Newsletters & & \\
\hline & & Publications & & \\
\hline & Exhibitions & & \\
\hline & & Presentations & & \\
\hline & & Educational activities & & \\
\hline & & Forums & & \\
\hline & & Other & & \\
\hline & & Other: & & \\
\hline
\end{tabular}

19.- Do you keep permanent communication channels with mass media, or just in case of crisis? Explain:

20.- Have you ever used campaign techniques as massive sending of postcards or emails. Explain:

21.- Have you set long-term targets for your communication activities? If so, what are they?

22.- Do you evaluate your communication activities? If so, please describe the method of your evaluation, and how you would then evaluate the success of your communication strategy - in terms of the targets you have reached, and targets you have not fully reached (yet)?

23.- Do you use techniques to control your relationships with mass media, to analyze the content of your articles and news that appear in mass media (to check how did the message arrive from your source through the journalist)?

24.- If it has been a failure in your communication strategy, do you try to find out the reason of why did it fail, and try to learn from it?

25.- Do you have independent (external) evaluation of your communication actions? 